\title{
12
}

\section{Changing patterns in China's agricultural trade after WTO accession}

\section{Chunlai Chen}

China's economy has been growing rapidly since the country's entry into the World Trade Organization (WTO) in 2001. The average annual growth rate of China's GDP was more than 9.8 per cent in 2002-05. ${ }^{1}$ China's foreign trade has been expanding even more rapidly than its overall economic growth, with the total value of foreign trade increasing from US $\$ 457$ billion in 2001 to US $\$ 1,263$ billion in 2005, and an annual growth rate of 28.6 per cent compared with 9.4 per cent during the 1990s. Undoubtedly, China's economy has benefited from entry into the WTO, especially from a more open and liberalised international trade regime. ${ }^{2}$

After entry into the WTO, China's agricultural trade also increased dramatically. Agricultural imports, however, increased more rapidly than agricultural exports. From 2002 to 2005, the annual growth rate of agricultural imports was 31.5 per cent, while that of agricultural exports was 11.6 per cent. As a result, in 2004 and 2005 agricultural imports exceeded agricultural exports. It is expected that China's next agricultural imports will continue to increase.

The impact of China's entry into the WTO on its agricultural sector has been a major concern to the Chinese government and has been the hottest topic among policymakers and academics in and outside China (for example, Anderson 1997; Cheng 1997; Development Research Centre 1998; Huang 1998; Huang and Chen 1999; Wang 1997). Some experts have argued for some time that, based on China's resource endowments and comparative advantage, after entry into the WTO, China's land-intensive farming sector would shrink but the labour-intensive horticultural, animal husbandry and processed agricultural product sectors would expand. As a result, China would import more land-intensive agricultural products, such as grains 
and vegetable oils, and would export more labour-intensive agricultural products, such as vegetables and fruit, animal products and processed agricultural products.

What has really happened in China's agricultural trade since entry into the WTO in 2001? Have there been any changes in China's revealed comparative advantage in agriculture and, therefore, in the patterns of China's agricultural trade? What factors have driven these changes? This chapter intends to analyse and answer these questions.

The chapter is structured as follows. The following section will briefly review international trade theories and discuss the implications on China's agricultural trade. The third section introduces the classification of agricultural trade data. The fourth section examines the changes in China's revealed comparative advantage in agriculture. The fifth section analyses the patterns of China's agricultural trade and examines the changes since WTO accession. The sixth section discusses the factors driving the changes in China's revealed comparative advantage and in the patterns of China's agricultural trade. The final section summarises the chapter.

\section{International trade and comparative advantage}

\section{A brief review of international trade theories}

The theory of comparative advantage was first proposed by David Ricardo in $1817^{3}$ and it remains the dominant explanation of why a country would specialise in exporting certain categories of goods and services and importing others. It can be seen as a cost-based explanation of international trade.

What underlying forces would create comparative advantage? Essentially, there are two explanations for why costs might differ between countries. First, one country might simply use the same resources more efficiently than another. Second, one country might be able to obtain key inputs more cheaply than another.

The Ricardian model is the first of the two explanations. According to Ricardian theory, comparative advantage is the result of international differences in the productivity of labour. A country has a comparative advantage in producing a good if it can produce that good in terms of other goods more efficiently than other countries. In the presence of international trade, countries would export goods that they produced relatively cheaply (more efficiently) compared with their trading partners and import goods that they produced relatively more expensively (less efficiently).

One of the most influential theories in international economics is the HeckscherOhlin model, ${ }^{4}$ which is the second of the two explanations. In this model, resource differences are the only source of trade, and comparative advantage is determined by international differences in the supplies of factors of production. The model 
shows that comparative advantage is influenced by the interaction between the resource endowments of countries (the relative abundance of factors of production) and the technology of production (which influences the relative intensity with which different factors of production are used in the production of different goods). The model predicts that countries will tend to have a comparative advantage and, therefore, to export goods or services that make intensive use of those factors of production with which they are relatively well endowed. Conversely, countries will tend to have a comparative disadvantage and, therefore, to import goods or services that make intensive use of factors of production with which they are relatively poorly endowed.

The Heckscher-Ohlin theory of international trade has been tested empirically by many researchers. Among others, Leamer's (1984) work is the most comprehensive. Later, Song (1996) adopted Leamer's approach and updated the research. The studies have demonstrated that resource endowments are powerful sources of international comparative advantage. The Heckscher-Ohlin model has been the most powerful and influential theory in explaining international trade.

Implications of international trade theory on China's agricultural trade

The most prominent characteristics of China's resource endowments in terms of agricultural production are scarcity of land resources but abundance of labour supply. China's per capita arable land is 0.11 hectare, only 43 per cent of the world average, while its per capita pasture land is 0.3 hectare, only 33 per cent of the world average. China has, however, an abundant labour supply: a population of 1.3 billion, nearly 60 per cent of whom live in rural areas, and with half of the labour force working in the agricultural sector.

According to the Heckscher-Ohlin theory of international trade and based on China's resource endowments in terms of agricultural production, it is possible to draw some generalised predictions.

First, overall China should have no comparative advantage in agriculture as agricultural production in general is a land-intensive activity and land is relatively scarce in China. As a result, China should be a net importer of agricultural products.

Second, China should have a comparative advantage in labour-intensive agricultural production, such as processed agricultural products, animal and horticultural products, while it should have a comparative disadvantage in landintensive agricultural production, such as grains, vegetable oil seeds and raw materials for textiles, such as cotton, wool and raw animal hides and skins. As a result, China should export more labour-intensive agricultural products and import more land-intensive agricultural products. 
Third, entry into the WTO has increasingly integrated China's economy into the world economy. This will improve resource allocation in the Chinese economy as well as in its agricultural sector as it increasingly specialises in the production of goods in which it has a comparative advantage. As a result, it is expected that China's comparative advantage in agriculture and its pattern of agricultural trade will change gradually. China's overall comparative advantage in agriculture can be expected to decline in general, and its comparative advantage in land-intensive agricultural production to decline in particular. Consequently, China's exports of agricultural products can be expected to move towards concentrating more and more on labour-intensive agricultural products, such as processed agricultural products, while its imports of agricultural products will move increasingly towards concentration on land-intensive agricultural products, such as grains, vegetable oil seeds and raw materials for textiles.

Are these predictions valid? In other words, are China's patterns of agricultural trade consistent with its resource endowments and based on its comparative advantage? In the following sections, we will find the answers.

\section{The classification of agricultural commodities and sources of data}

To analyse patterns of agricultural trade, the first step is to identify the coverage of agricultural commodities in international trade. In this chapter, the classification of agricultural commodities in international trade is based on the Harmonised System (HS) of Trade Classification 1992. Table 12.1 presents the product coverage used in this chapter and the product coverage in the Uruguay Round Agreement on Agriculture (URAA). The product coverage in this chapter and in the URAA are very similar. The major difference is that the product coverage in this chapter includes fish and fish products. The main reason for this is that fish and fish products are very important agricultural products in China's international trade, and are produced mainly from aquaculture in China.

The agricultural trade data are from the United Nations Statistics Division's Commodity Trade Statistics Database, COMTRADE. All the values of agricultural trade data presented in this chapter are at 2000 constant US dollar prices.

For the purpose of analysing the pattern of China's agricultural trade, the agricultural trade data are grouped in two ways. First, the agricultural trade data are divided into five categories based on the nature of commodities

- the group of cereals, edible vegetable oil seeds and vegetable oils

- the group of horticultural products 


\section{Table 12.1 Comparison of agricultural product coverage}

Product coverage in this chapter

HS Chapters 1-24, plus

HS Headings $41.01-3$ (hides and skins)

HS Heading 43.01 (raw furs)

HS Headings 50.01-3 (raw silk and silk waste)

HS Headings 51.01-3 (wool and animal hair)

HS Headings 52.01-3

(raw cotton, waste and carded or combed cotton)

HS Heading 53.01 (raw flax)

HS Heading 53.02 (raw hemp)
Product coverage in the URAA

HS Chapters 1-24

(less fish and fish products, plus)

HS Code 2905.43 (mannitol)

HS Code 2905.44 (sorbitol)

HS Heading 33.01 (essential oils)

HS Headings 35.01-5

(albuminoidalsubstances, modified

starches, glues)

HS Code 3809.10 (finishing agents)

HS Code 3823.60 (sorbitol n.e.p.)

HS Headings 41.01-3 (hides and skins)

HS Heading 43.01 (raw furs)

HS Headings $50.01-3$

(raw silk and silk waste)

HS Headings 51.01-3

(wool and animal hair)

HS Headings 52.01-3

(raw cotton, waste and carded or

combed cotton)

HS Heading 53.01 (raw flax)

HS Heading 53.02 (raw hemp)

Sources: The Uruguay Round Agreement on Agriculture and author's own classification.

- the group of animal products (including fish)

- the group of processed agricultural products (including processed fish products)

- the group of raw materials for textiles.

Second, the agricultural trade data are grouped into two categories based on the factor intensity of production

- the group of land-intensive agricultural products, which includes cereals, vegetable oil seeds and vegetable oils, and raw materials (excluding silk) for textiles

- the group of labour-intensive agricultural products, which includes processed agricultural products, animal products, horticultural products and silk. 
Agricultural trade data for the period 1995-2005 based on the above classifications are presented in Appendix Tables 12.1 and 12.2.

\section{Revealed comparative advantage}

It is difficult to measure comparative advantage directly; an alternative is to measure it indirectly. The most common approach is the principle of revealed comparative advantage (RCA) proposed by Balassa (1965). It argues that, since trade is generated by underlying comparative advantage, we can use data on exports and imports to infer this underlying pattern of comparative advantage. This principle has given rise to a number of indicators of revealed comparative advantage.

One of the measures is the net export ratio $\left(N E R_{i j}\right)$, which is defined as: $\operatorname{RCA}\left(N R_{i j}\right)=\left(X_{i j}-M_{i j}\right) /\left(X_{i j}+M_{i j}\right)$ where $X_{i j}$ are the exports of goods 'i' by country 'j' and $M_{i j}$ are the imports of goods 'i' into country 'j'.

The rationale behind the index is that countries are revealed as having a comparative advantage in a particular good if they export more of it than they import. To simply consider net exports, however, might be misleading where, for example, we compare a large and a small country. For this reason, net exports are divided by total trade (exports plus imports). Net export ratios have a minimum value of -1 (the country only imports the good concerned) and a maximum value of +1 (the country only exports the good). Positive values are taken to reveal a comparative advantage and negative values are taken to reveal a comparative disadvantage.

RCA indices, however, have one major flaw. The principle of revealed comparative advantage presumes that observed trade flows are generated by underlying comparative advantage and disadvantage. It is this that allows us to use observed trade data to infer the underlying pattern of comparative advantage. Observed trade flows are, however, not created only by underlying economic forces, but are often affected significantly by government policies with respect to international trade. This problem has been potentially more serious for trade in agricultural products than in manufactured goods. With the establishment of the WTO and the implementation of the URAA, however, liberalisation of trade in agriculture has advanced somewhat. As a result, we might argue that the observed exports and imports of agricultural products in recent years have been affected less than previously by trade policies, although distortions from government interventions remain very important in this sector. 
Revealed comparative advantage in China's agriculture

Appendix Table 12.3 presents China's revealed comparative advantage indices calculated by using the measure of net export ratio for agricultural products for the period from 1992 to 2005.

In terms of the commodity groups. China has a revealed comparative advantage in horticultural products, processed agricultural products and animal products, but a revealed comparative disadvantage in cereals, vegetable oil seeds and vegetable oils and in raw materials for textiles.

In terms of factor intensity of production. China has a revealed comparative advantage in labour-intensive agricultural products, but a revealed comparative disadvantage in land-intensive agricultural products.

In general, the above patterns are consistent with China's resource endowments.

\section{Changes in revealed comparative advantage in China's agriculture}

During the period from 1992 to 2005, China's revealed comparative advantage in agriculture changed gradually. As shown in Figure 12.1, China's revealed comparative

Figure 12.1 China's revealed comparative advantage indices (NER) of the whole agricultural sector, 1992-2005

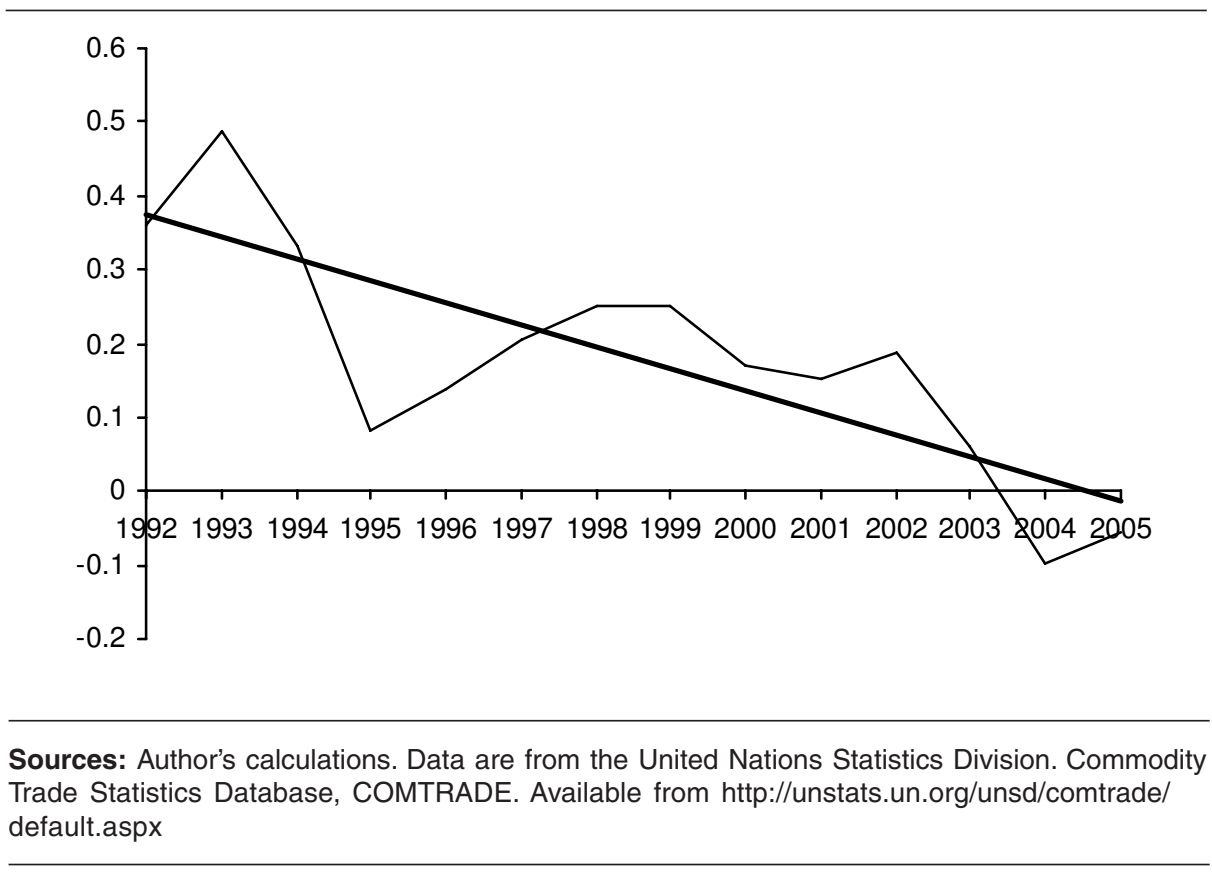


advantage in the whole agricultural sector presented a declining trend, especially after 2002. The values of China's revealed comparative advantage indices for the whole agricultural sector declined from about 0.4 in the early 1990 s to about 0.2 in 2002, and declined further to -0.09 in 2004 before rising slightly to -0.06 in 2005 .

In terms of agricultural commodity groups, as shown in Figure 12.2, during the period 1992-2005, the values of the revealed comparative advantage indices for processed agricultural products, horticultural products and animal products were positive. While the values of the revealed comparative advantage indices for processed agricultural products increased marginally, the values for horticultural and animal products declined especially quickly after the early 2000s. For horticultural products, the values of the revealed comparative advantage indices declined from more than 0.8 in the early 1990 s to about 0.7 in the late $1990 \mathrm{~s}$, and to about 0.6 in the early 2000s. For animal products, the values declined from about 0.6 in the early and mid 1990s to about 0.4 in the late 1990s, and dropped further to about 0.2 in the early 2000s.

From 1992 to 2005, the values of the revealed comparative advantage indices for cereals, vegetable oil seeds and vegetable oils, and raw materials for textiles were negative and declined especially quickly after 2003. For cereals, vegetable oil seeds and vegetable oils, the values declined from about -0.2 in the early 1990 s to about -0.3 in the late $1990 \mathrm{~s}$, and to about -0.5 in the early $2000 \mathrm{~s}$. For raw materials for textiles, the values declined from about -0.4 in the early 1990 s to about -0.5 in the late 1990s, and dropped further to about -0.8 in the early 2000 s.

In terms of factor intensity of production, as shown in Figure 12.3, although China has a revealed comparative advantage in labour-intensive agricultural products, the values of the revealed comparative advantage indices have declined continuously, especially since the late 1990s. The overall values of the revealed comparative advantage indices for labour-intensive agricultural products declined from more than 0.6 in the early 1990 s to about 0.5 in the late 1990 s, and to just more than 0.4 in the early 2000 s.

The overall values of the revealed comparative advantage indices for land-intensive agricultural products declined from about -0.3 in the 1990 s to about -0.4 in 2002 , and further declined to -0.8 in 2004, with a slight increase to -0.7 in 2005.

The above analysis has revealed several important findings. First, China's agriculture as a whole has been losing comparative advantage at an accelerated rate since entry into the WTO. Second, although China still has a comparative advantage in labour-intensive agricultural products, apart from processed agricultural products, whose comparative advantage increased marginally, the levels of comparative advantage of horticultural and animal products have been declining 
Figure 12.2 China's revealed comparative advantage indices (NER) of agricultural products by commodity groups, 1992-2005

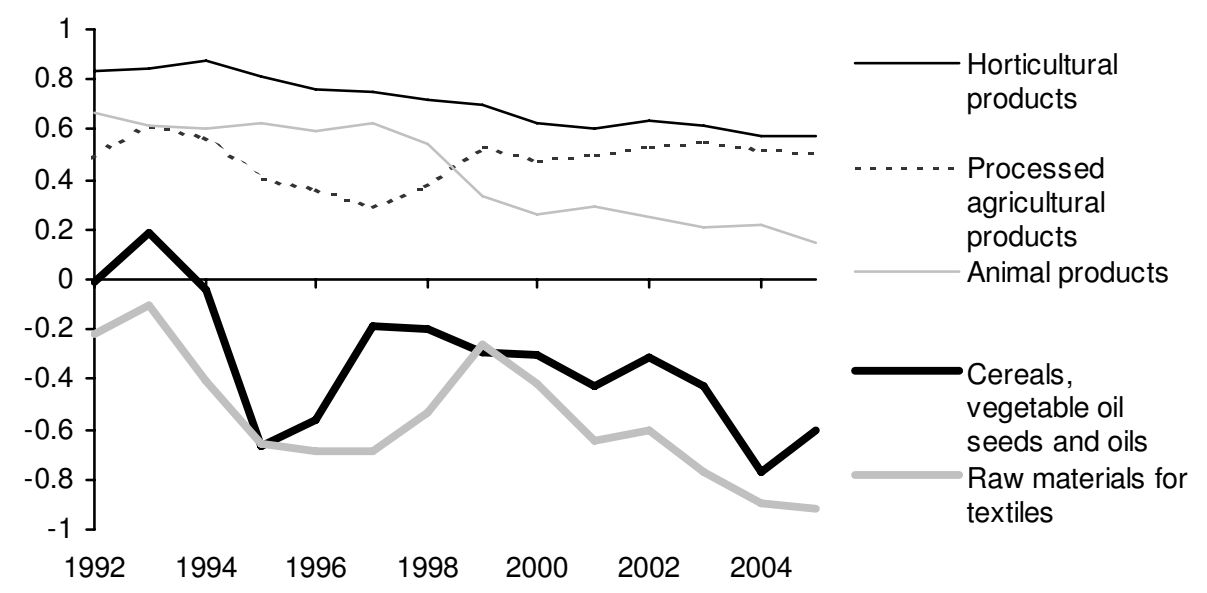

Sources: Author's calculations. Data are from the United Nations Statistics Division. Commodity Trade Statistics Database, COMTRADE. Available from http://unstats.un.org/unsd/comtrade/ default.aspx

Figure 12.3 China's revealed comparative advantage indices (NER) for agricultural products by factor intensity of production, 1992-2005

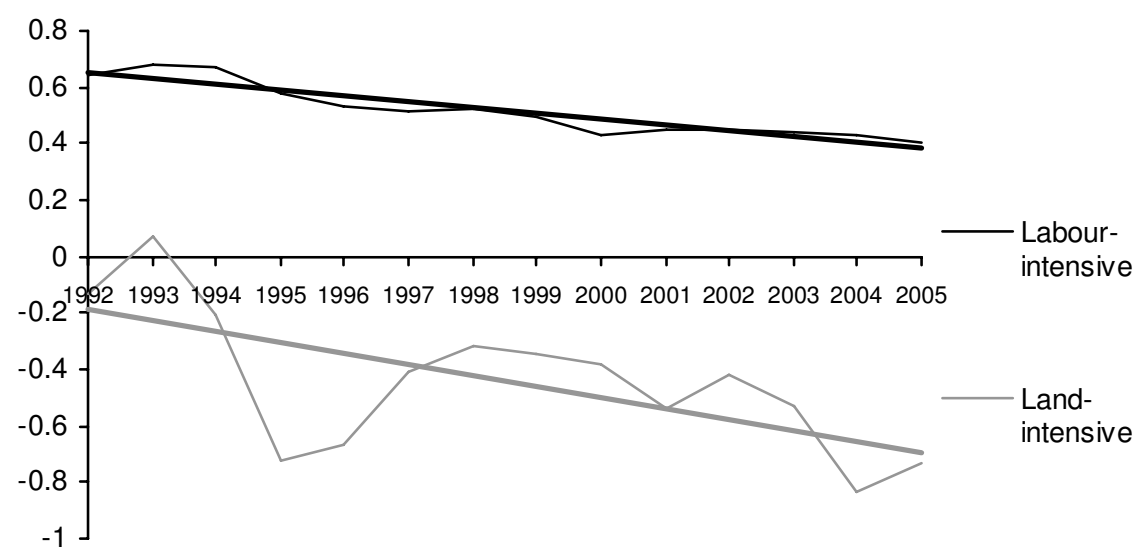

Sources: Author's calculations. Data are from the United Nations Statistics Division. Commodity Trade Statistics Database, COMTRADE. Available from http://unstats.un.org/unsd/comtrade/ default.aspx 
especially rapidly since entry into the WTO. Third, China has no comparative advantage in land-intensive agricultural products, and its comparative advantage has been declining quickly and dramatically, particularly since entry into the WTO.

These findings are consistent with the expectations introduced in the second section about China's comparative advantage in agriculture after entry into the WTO. If, however, China's agricultural trade is based on its comparative advantage, as revealed above, it could be expected that this would be reflected in the detailed patterns of China's agricultural trade.

\section{Patterns of China's agricultural trade}

As shown in Figure 12.4, before entry into the WTO, between 1992 and 2001, China's agricultural trade had stagnated, although with large fluctuations. After entry into the WTO in 2001, China's agricultural trade increased dramatically to US $\$ 50$ billion in 2005, an increase of 90 per cent from 2001. Agricultural imports, however, increased more rapidly than agricultural exports. From 2002 to 2005, the annual growth rate of agricultural imports was 31.5 per cent, while that of agricultural exports was 11.6 per cent. In 2005, the value of agricultural imports surged to

Figure 12.4 China's agricultural trade, 1992-2005 (at constant 2000 US\$prices)

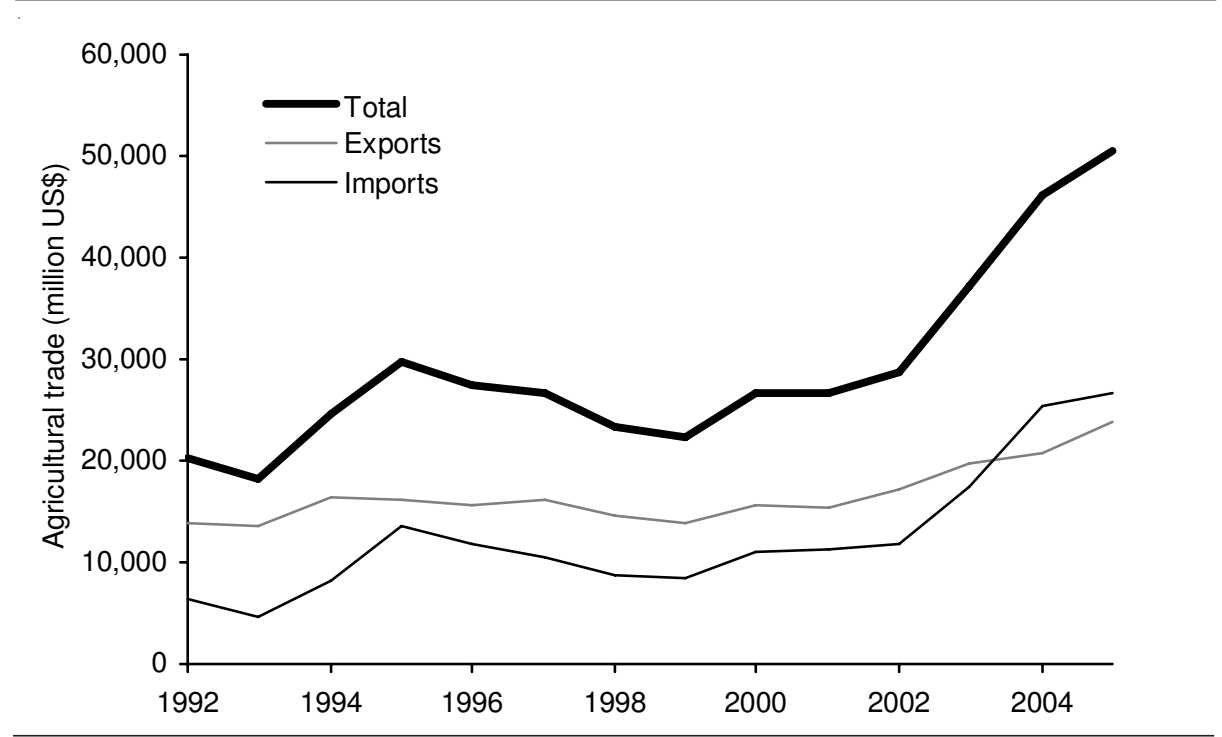

Source: Data are from the United Nations Statistics Division. Commodity Trade Statistics Database, COMTRADE. Available from http://unstats.un.org/unsd/comtrade/default.aspx 
US $\$ 26$ billion, increasing 136 per cent from 2001. The value of agricultural exports was US $\$ 23.81$ billion, 55 per cent higher than in 2001. As a result, in 2004 and 2005, agricultural imports exceeded agricultural exports and China became a net importer of agricultural products. It is expected that the relatively higher growth of agricultural imports will continue.

In terms of the trade pattern of agricultural commodity groups, Figure 12.5 presents China's agricultural exports based on commodity groups for the period from 1992 to 2005. As the figure shows, China's agricultural exports were dominated by processed agricultural products, followed by animal and horticultural products. The export values of cereals, vegetable oil seeds and vegetable oils and, in particular, raw materials for textiles are small.

In terms of imports, as Figure 12.6 shows, China's imports of agricultural products were dominated overwhelmingly by cereals, vegetable oil seeds and vegetable oils, followed closely by raw materials for textiles. The imports of animal products, processed agricultural and horticultural products were relatively low but have been rising rapidly since 2003.

Figure 12.5 China's agricultural exports by categories, 1992-2005 (at constant 2000 US prices)

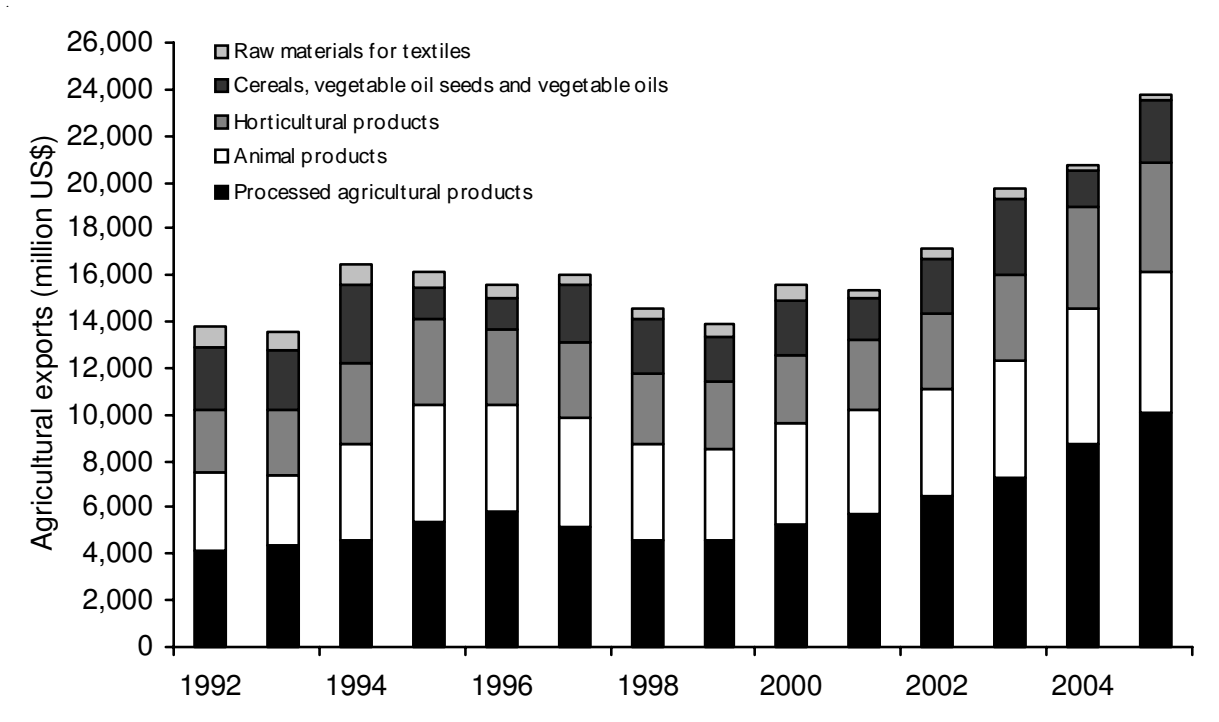

Source: Data are from the United Nations Statistics Division. Commodity Trade Statistics Database, COMTRADE. Available from http://unstats.un.org/unsd/comtrade/default.aspx 
The above analyses have revealed three important points. First, China has become a net importer of agricultural products since 2004 and it will remain in that position in its international trade. Second, China's agricultural exports are dominated overwhelmingly by labour-intensive agricultural products, particularly processed agricultural products, which have accounted for about 40 per cent of China's total agricultural exports, followed by animal and horticultural products. Third, China's agricultural imports are dominated overwhelmingly by land-intensive agricultural products, in particular cereals, vegetable oil seeds and vegetable oils, followed by raw materials for textiles. These patterns in China's agricultural trade are consistent with China's comparative advantage, as revealed in the above section.

Figure 12.6 China's agricultural imports by categories, 1992-2006 (at constant 2000 US\$ prices)

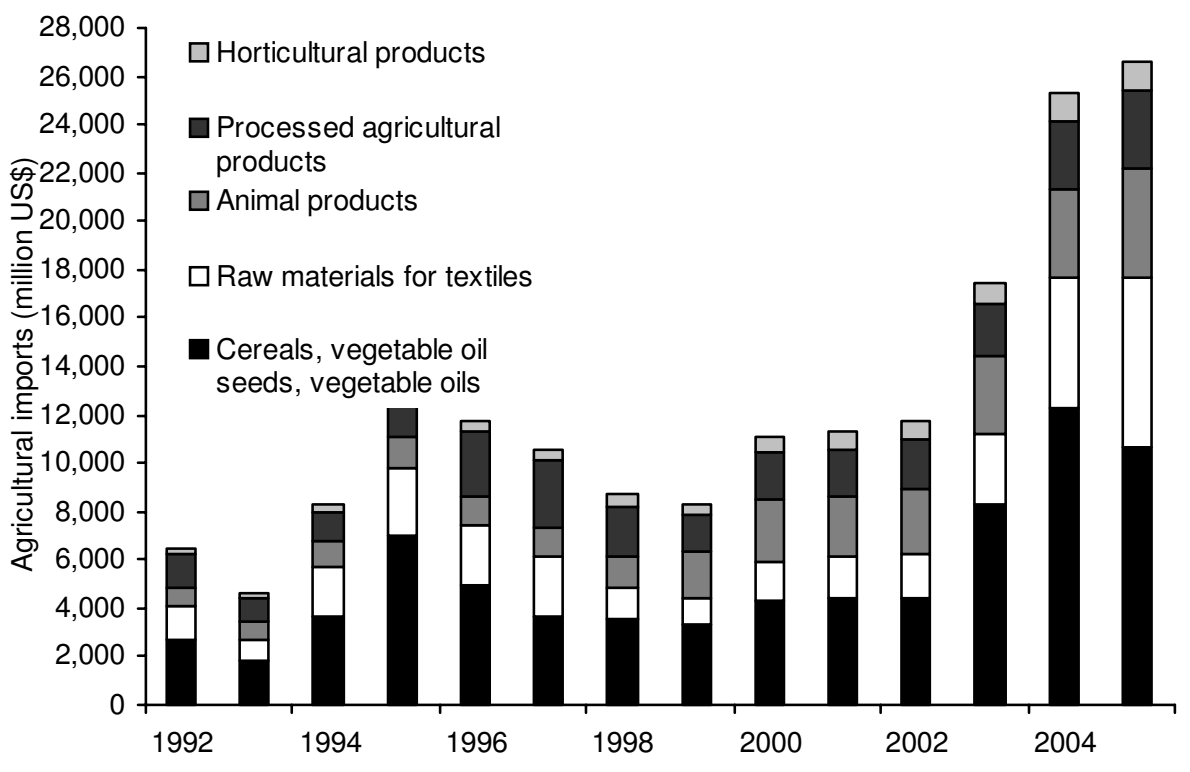

Source: Data are from the United Nations Statistics Division. Commodity Trade Statistics Database, COMTRADE. Available from http://unstats.un.org/unsd/comtrade/default.aspx 
Changes in the patterns of China's agricultural trade by commodity groups

Have there been any changes in the patterns of China's agricultural trade since China's accession into the WTO? To answer this question, I compare China's agricultural trade patterns for the two periods of 1992-2001 and 2002-05 by commodity groups and by factor intensity of production.

Figure 12.7 shows the composition of China's agricultural exports by commodity groups for the two periods of 1992-2001 and 2002-05.

Figure 12.7 reveals several interesting points. First, China's agricultural exports are dominated by processed agricultural products, animal and horticultural products. Their combined share accounted for 81.2 per cent of China's total agricultural exports during 1992-01 and 86.1 per cent during 2002-05. Second, it is interesting to note that between the two periods of 1992-2001 and 2002-05, except for the group of processed agricultural products, whose export share increased by 7.3 percentage points, the export shares of all the other agricultural commodity groups declined. The export share of horticultural products declined by 0.7 percentage points, the share of animal products declined by 1.7 percentage points, while the export shares of the commodity groups of cereals, vegetable oil seeds and vegetable oils, and raw materials for textiles declined by 2.6 percentage points and 2.3 percentage points respectively. Third, these changes in the export shares of the commodity groups are consistent with the changes in their comparative advantage revealed in the above section. Fourth, China's agricultural exports are moving towards concentrating more and more on processed agricultural products.

Figure 12.8 shows the composition of China's agricultural imports by commodity groups for the two periods of 1992-2001 and 2002-05.

Figure 12.8 also reveals several interesting points. First, China's imports of agricultural products are dominated by the commodity groups of cereals, vegetable oil seeds and vegetable oils, and raw materials for textiles. Their combined share of China's total agricultural imports increased from 60.6 per cent in 1992-2001 to 65 per cent in 2002-05. Second, between the two periods of 1992-2001 and 2002-05, the import share of animal products increased by 2.6 percentage points, while the share of processed agricultural products declined by 7.4 percentage points. Third, China's agricultural imports are moving towards concentrating more and more on the commodity groups of cereals, vegetable oil seeds and vegetable oils, and raw materials for textiles. 


\section{Figure 12.7 Shares of China's agricultural exports by commodity groups, 1992-2001 and 2002-05 (per cent)}

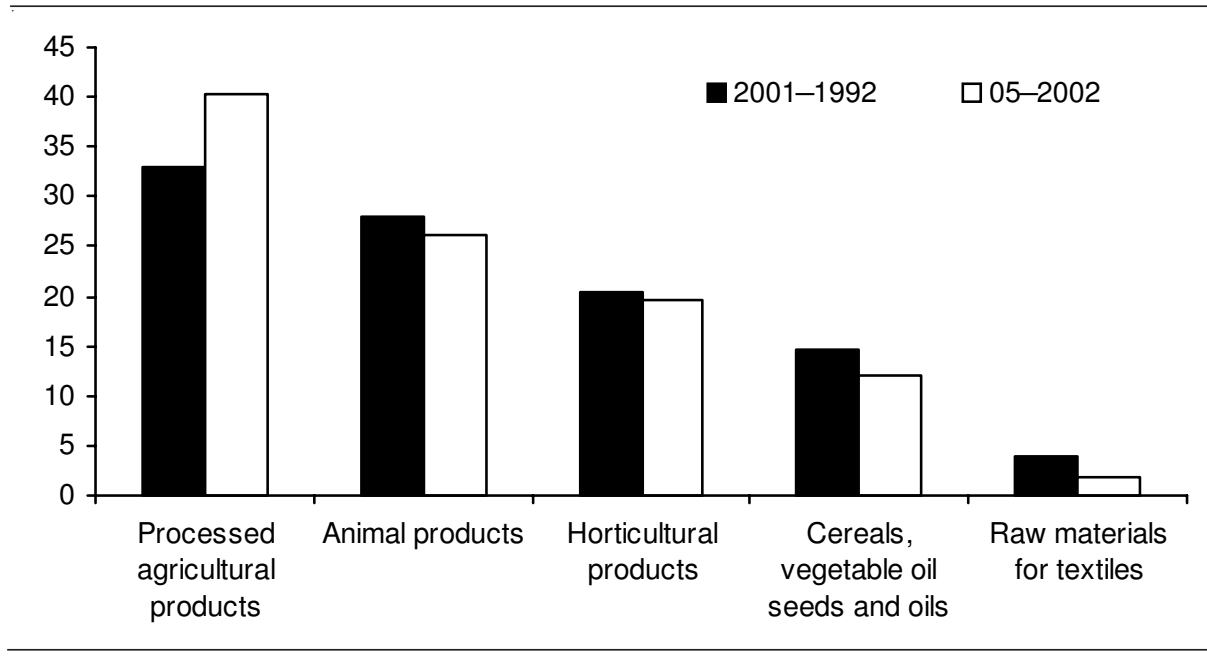

Source: Author's calculations. Data are from the United Nations Statistics Division. Commodity Trade Statistics Database, COMTRADE. Available from http://unstats.un.org/unsd/comtrade/ default.aspx

Figure 12.8 Shares of China's agricultural imports by commodity groups, 1992-2001 and 2002-05 (per cent)

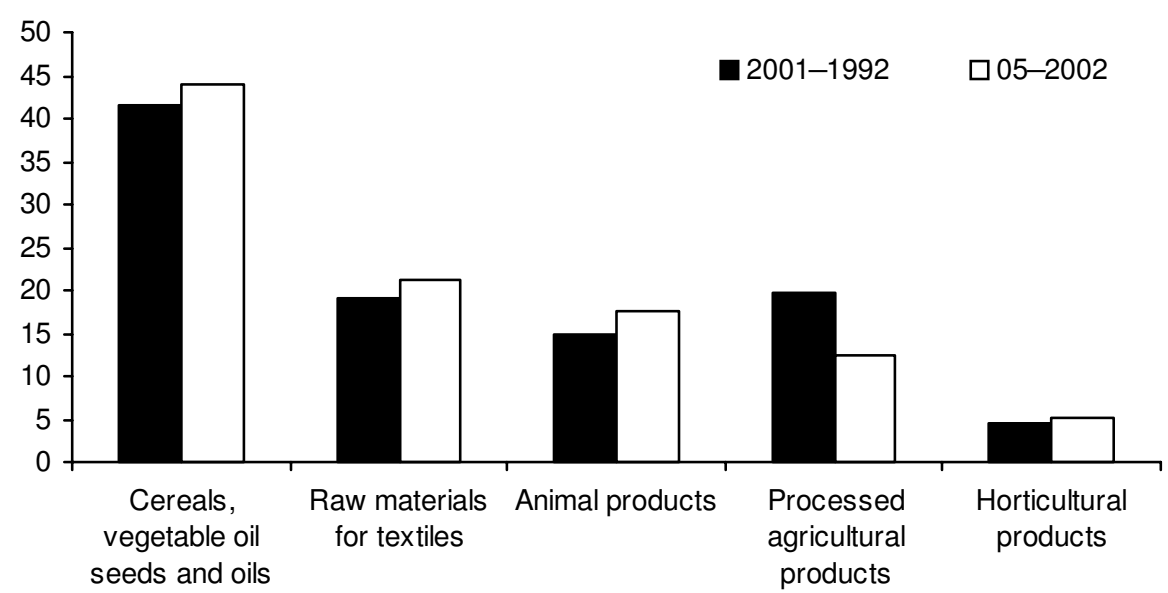

Sources: Author's calculations. Data are from the United Nations Statistics Division. Commodity Trade Statistics Database, COMTRADE. Available from http://unstats.un.org/unsd/comtrade/ default.aspx 
Changes in the patterns of China's agricultural trade by factor intensity of production

Figure 12.9 shows the composition of China's agricultural exports by factor intensity of production. China's agricultural exports were dominated overwhelmingly by labourintensive agricultural products. For the period from 2002 to 2005, labour-intensive agricultural products accounted for 86.1 per cent of China's total agricultural exports, while land-intensive agricultural products accounted for only 13.9 per cent of China's total agricultural exports. Compared with the period from 1992 to 2001, in the period from 2002 to 2005 , the share of labour-intensive agricultural products in China's total agricultural exports increased by 4.9 percentage points, while the share of land-intensive agricultural products declined by the same amount.

China's agricultural imports were dominated by land-intensive agricultural products, which accounted for 60.6 per cent and 65 per cent of China's total agricultural imports during the two periods of 1992-2001 and 2002-05 respectively

Figure 12.9 Shares of China's agricultural exports by factor intensity of production, 1992-2001 and 2002-05 (per cent)

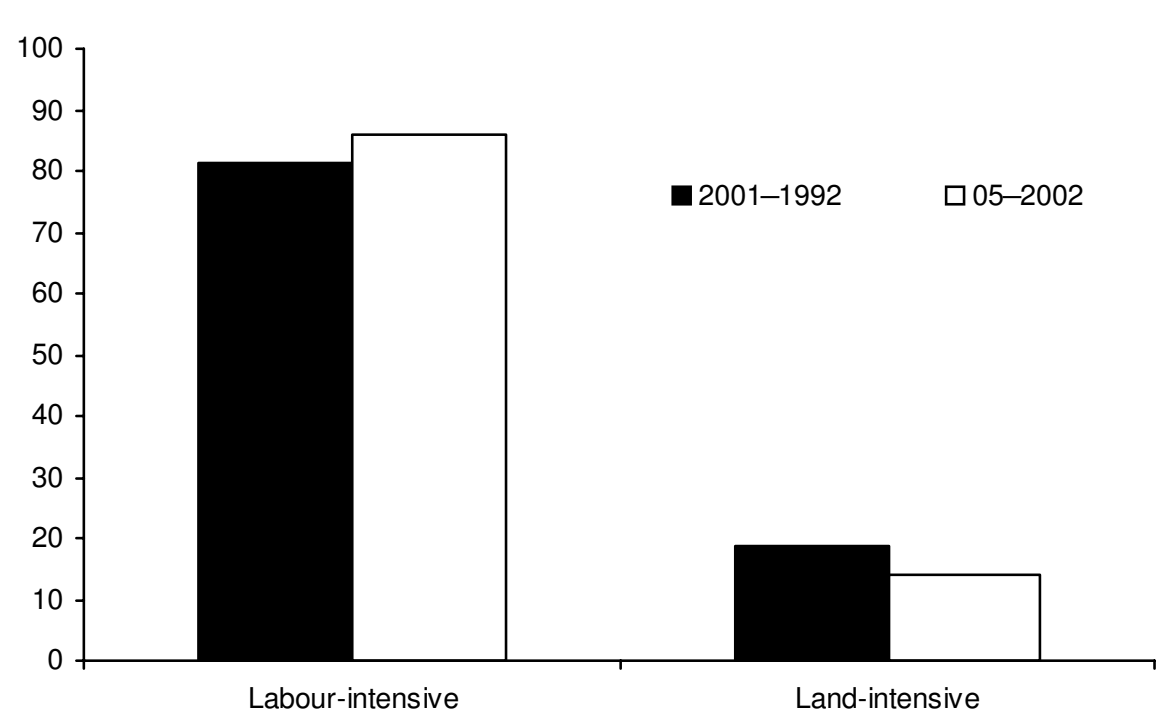

Sources: Author's calculations. Data are from the United Nations Statistics Division. Commodity Trade Statistics Database, COMTRADE. Available from http://unstats.un.org/unsd/comtrade/ default.aspx 
(Figure 12.10). Labour-intensive agricultural products accounted for 39.4 per cent and 35 per cent of China's total agricultural imports in the same two periods. The share of land-intensive agricultural products in China's total agricultural imports increased by 4.4 percentage points between 1991-2001 and 2002-05, while the share of labour-intensive agricultural products declined by the same amount.

It is clear that China has been exporting mainly labour-intensive agricultural products and importing mainly land-intensive agricultural products. This pattern of agricultural trade has been strengthened in the period from 2002 to 2005. The above findings reveal that since accession into the WTO the patterns of China's agricultural trade have been moving closer to its comparative advantage and are more consistent with its resource endowments of scarce land resources and abundant labour supply.

\section{Figure 12.10 Shares of China's agricultural imports by factor intensity of production, 1992-2001 and 2002-05 (per cent)}

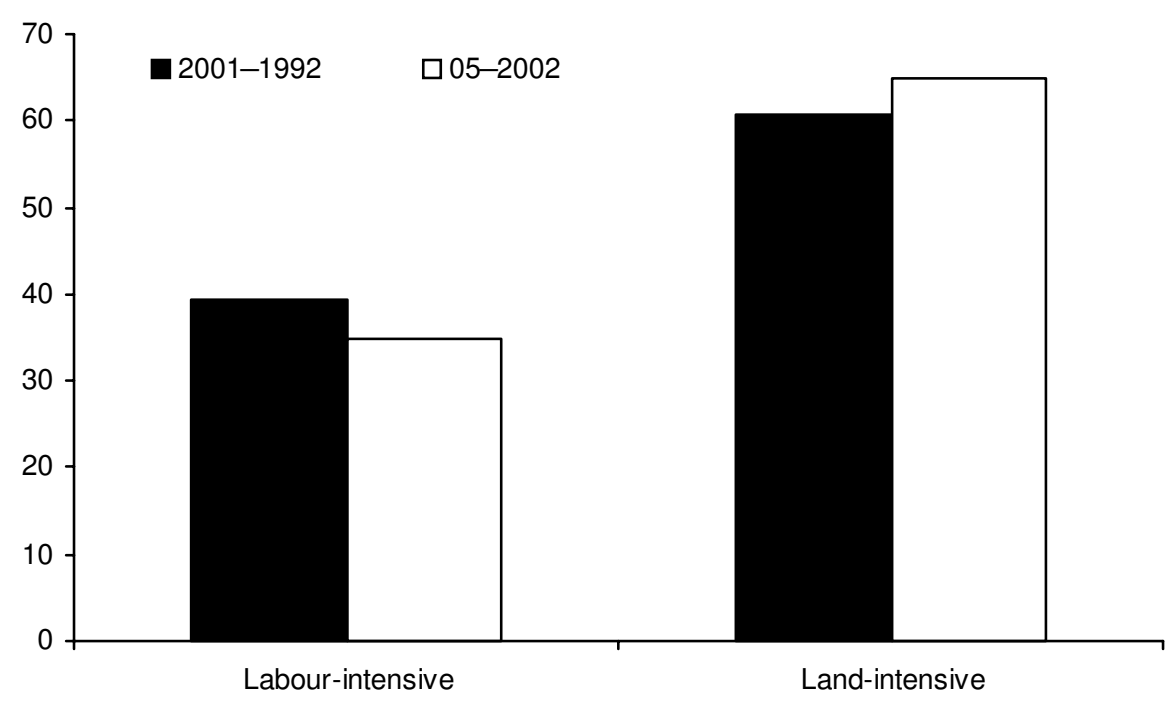

Sources: Author's calculations. Data are from the United Nations Statistics Division. Commodity Trade Statistics Database, COMTRADE. Available from http://unstats.un.org/unsd/comtrade/ default.aspx 


\section{Factors driving the changes in revealed comparative advantage in China's agriculture}

What are the reasons for the changes of China's revealed comparative advantage in agriculture? Empirical studies have shown that for many countries during the process of economic growth, the nation's comparative advantage in agriculture declines and, for those nations where arable land is scarce, the comparative advantage in agriculture tends to decline more rapidly (Anderson 1990). Undoubtedly, the changes of China's revealed comparative advantage in agriculture during the period from 1992 to 2005 have been the result mainly of the fast economic growth and dramatic structural changes happening in China, especially since entry into the WTO.

\section{Economic factors}

Since its entry into the WTO in 2001, China's economy has been growing very rapidly, with an average annual growth rate of more than 9.8 per cent. This has led to changes in the structure of China's economy. During the period from 2001 to 2004 , the growth of the manufacturing and services sectors was much faster than the growth of the agricultural sector. Consequently, agricultural sector's share of China's economy has been declining. The share of agricultural GDP in China's total GDP declined from 15 per cent in 2001 to 13.8 per cent in 2004 (calculated from various issues of the China Statistical Yearbook [State Statistical Bureau]).

With the declining trend of the agricultural sector in China's economy, the structure of the agricultural economy has also changed. Within the agricultural economy, although the farming sector remained the most important sector, its share has been declining, from 55.2 per cent in 2001 to 50 per cent in 2004. Meanwhile, the animal husbandry and fishery sectors have been growing rapidly, with their share increasing from 41.2 per cent in 2001 to 46 per cent in 2004 (calculated from various issues of the China Statistical Yearbook [State Statistical Bureau]).

These changes demonstrate that, with China's rapid economic growth, especially since entry into the WTO, the comparative advantage of China's agricultural sector has been declining in general, and the comparative advantage of China's farming sector has been declining in particular. This changing pattern is consistent with China's resource endowments. It is also an indication of the improvement in resource allocation among China's economic sectors.

China's remarkable industrial growth played a large part in driving up agricultural imports. More than 30 per cent of the growth in China's agricultural imports in 
2004 came from raw materials used in the production of non-food manufactured products: cotton, wool, animal hides and rubber, as well as other agriculturalderived products used in industrial production. In particular, growing textile production is generating demand for cotton and wool that is beyond China's production capacity. China's exports of apparel and footwear grew in double digits during 2004 and its domestic retail sales of apparel, shoes and textiles rose 18.7 per cent. Chinese yarn production grew 13.9 per cent and cloth production grew 18.8 per cent during 2004 (Gale 2005).

The continued increase in per capita income in China has led not only to a rise in food consumption, but to a change in the structure of that consumption. Since the late 1990s, China has dramatically increased imports of vegetable oil seeds (mainly soya beans) and vegetable oils (mainly soya bean and palm oils). Soya beans are crushed to produce vegetable oil for human consumption and animal feed to help the rapid growth in animal production. Driven by consumer and food industry demands, since the early 2000s, China has also increased imports of meat, fish, milk, cheese, wines and fruit.

\section{Trade barriers}

Apart from the economic factors discussed above, other factors could affect China's revealed comparative advantage in agriculture. As discussed above, revealed comparative advantage indices are not created only by underlying economic forces but are often affected significantly by government policies affecting international trade. This problem has been more serious for trade in agricultural products. There has been some liberalisation over the past decade, but egregious trade barriers in agricultural products remain. In particular, industrialised countries have increasingly resorted to sanitary and phyto-sanitary (SPS) measures for animal and plant health and technical barriers to trade (TBT) to block agricultural imports, especially from developing countries, seriously affecting developing countries' exports of the agricultural products in which they have a comparative advantage.

Chinese farmers and exporters had anticipated a large, positive impact on exports of agricultural products from accession to the WTO, especially for labour-intensive agricultural products such as vegetables, fruit, animal and aquatic products. In fact, these products have been hit hardest by the need to meet significant SPS standards and this has slowed growth in these agricultural exports.

According to official Chinese government sources, SPS measures and TBT have resulted in huge direct losses for China's agricultural exports. The indirect losses are even greater. In 2001, about US $\$ 7$ billion worth of Chinese exports were affected 
by SPS measures and TBT. In early 2002, the European Union began to ban imports of Chinese animal-derived food, seafood and aquatic products, resulting in a 70 per cent slump in China's aquatic product exports during the second half of that year (Ministry of Commerce 2005). Also, according to an investigation by China's Ministry of Commerce, about 90 per cent of China's exporters of foodstuffs, domestic produce and animal by-products were affected by foreign TBT and suffered losses totalling US\$9 billion in 2002 (China Daily 2003).

China's recent difficulties with SPS barriers have been mainly with the European Union, Japan and the United States. ${ }^{5}$ These three economies accounted for 41 per cent, 30 per cent and 24 per cent respectively of China's trade losses attributed to SPS measures in 2002 (Zhu 2003). Because failure to pass SPS inspection often leads to closer inspection of future exports, China's agricultural products have confronted much stricter inspections in these markets after several SPSrelated problems.

For example, in November 2001, 300 metric tonnes of shrimp shipped from Zhoushan in Zhejiang Province to the European Union were discovered to contain 0.2 parts per billion of chloramphenicol (Dong and Jensen 2004). As a result, the European Union suspended imports of Chinese products of animal origin intended for human consumption or for use in animal feeds. Affected products included rabbit and poultry meat and crustaceans such as shrimp and prawns. Later, other countries, including Hungary, Russia and Japan, implemented stricter inspections of poultry meat from China. As a consequence, exports of poultry meat from China declined by about 33 per cent in 2002 compared with the previous year.

In 2002, Japan strengthened the allowable maximum residual limit (MRL) of chlorpyrifos for spinach from 0.1 parts per million to 0.01 parts per million. As a result, in July 2002, Japan blocked imports of frozen spinach from China after finding the presence of pesticides. Before this ban, annual imports from China were worth about US\$30-35 million, and accounted for 99 per cent of Japan's annual imports of 40,000-50,000 metric tonnes of spinach. Japan's restriction on Chinese frozen spinach lasted for about eight months (until February 2003). In May 2003, after detecting higher than permitted pesticide residue, Japan again advised importers not to import Chinese frozen spinach. This ban was not lifted until June 2004. As a result, (Figure 12.11), China's exports of spinach to Japan dropped dramatically, from the highest level of US\$34 million in 2001, to US\$14 million in 2002 and US\$4 million in 2003. In 2004 and 2005, China's exports of spinach to Japan recovered slightly, but were still lower than the 1994 export level. 
Figure 12.11 China's exports of spinach and cabbage to Japan, 1992-2005 (at constant 2000 US\$ prices)

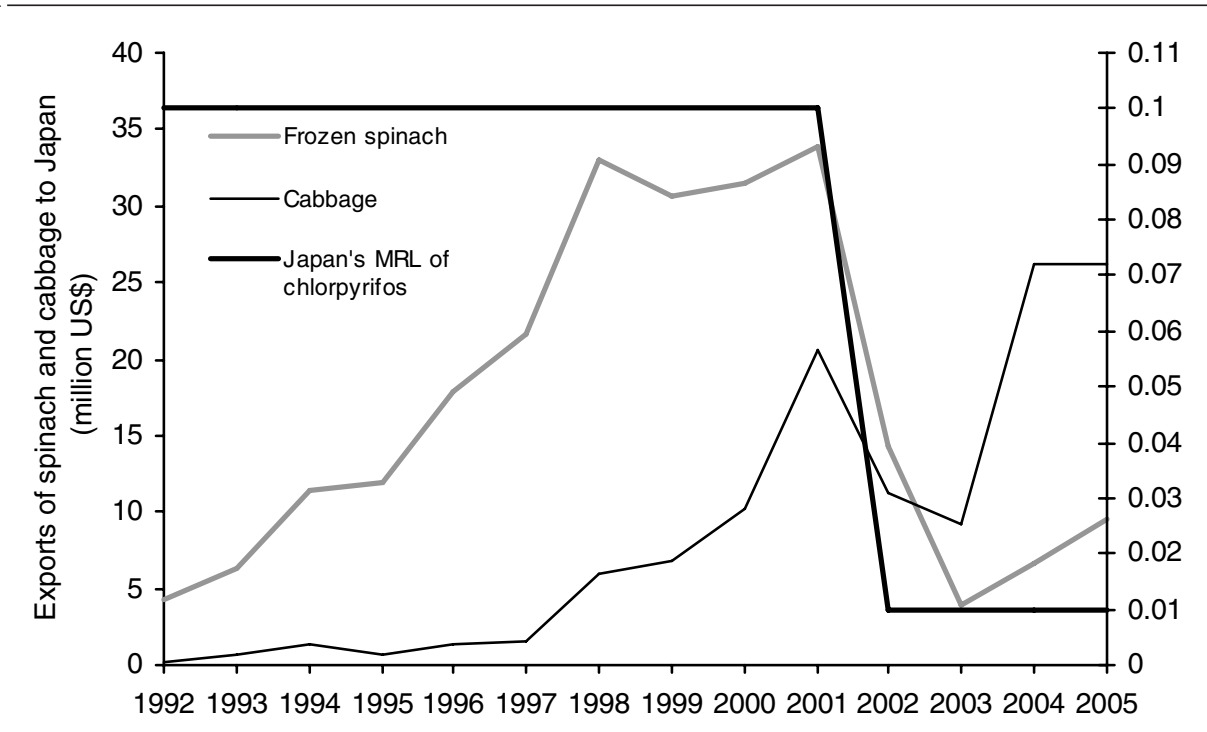

Source: United Nations Statistics Division. Commodity Trade Statistics Database, COMTRADE. Available from http://unstats.un.org/unsd/comtrade/default.aspx

The stricter standards for chlorpyrifos on spinach have effected China's exports of other vegetables to Japan. For example, China's exports of cabbage to Japan declined sharply from US $\$ 20.5$ million in 2001 to US $\$ 11.2$ million and US $\$ 9.2$ million in 2002 and 2003 respectively. China's exports of lettuce to Japan declined from US $\$ 360,000$ in 2001 to US $\$ 180,000$ and US $\$ 60,000$ in 2002 and 2003 respectively. In 2005, China's exports of lettuce to Japan amounted to US $\$ 280,000$, still lower than in 2001.

In 2006, Japan introduced the 'Positive List System for Agricultural Chemical Residues in Foods' (Ministry of Health, Labour and Welfare of Japan 2006), which took effect on 29 May 2006. Under this system, agricultural chemicals include pesticides, feed additives and veterinary drugs in 797 categories. The system sets 53,862 standards for maximum residue limits. The uniform limit will be applied to agricultural chemicals for which MRLs are not established. The uniform limit is $0.01 \mathrm{ppm}$, which means for 100 tonnes of agricultural products, the agricultural chemical residuals cannot exceed $1 \mathrm{gram}$. 
Japan is the largest market for Chinese exports of agricultural products, accounting for 31 per cent of China's total agricultural exports in 2005. The introduction of the Positive List System will have a significant impact on China's agricultural exports to Japan. From January to April 2006, the growth rate of China's agricultural exports to Japan declined substantially, because many agricultural export companies were worried that their products would be refused entry due to the much stricter standards (Cai Jing 2006).

Currently, China's exports of seafood, vegetables and fruit, tea, honey, poultry and red meat are encountering the most severe SPS problems. United States' technical standards preclude imports of beef, pork and poultry meat into the United States in an effort to prevent the import of highly contagious animal diseases that are endemic in China, including foot-and-mouth disease. From August 2002 to July 2003, the United States Food and Drug Administration (FDA) refused entry to 1,285 shipments of Chinese foodstuffs. Agricultural and aquatic products accounted for 630 of these shipments, or nearly half of all refusals (Dong and Jensen 2004). Most recently, from June 2005 to May 2006, the FDA refused entry to 1,925 Chinese shipments, of which 945 shipments were agricultural products, accounting for 49 per cent of the total refusals (US FDA 2006). Most refusals resulted from violations of SPS measures. Excessive pesticide residues, low food hygiene, unsafe additives, contamination and misuse of veterinary drugs have been major issues.

Although the WTO's SPS agreement requires members to ensure that SPS measures are based on sufficient scientific evidence, there are some well-founded concerns that countries abuse SPS measures by using them as trade barriers. Because of very low production and labour costs, some agricultural products exported from China are very competitive in world markets. Consequently, importing countries might look to restrict imports from China by setting relatively high standards or strict inspections in order to protect domestic markets.

\section{Conclusions}

Entry into the WTO has boosted China's agricultural trade, especially its agricultural imports. The rapid growth of China's agricultural imports is mainly a result of the rapid increase in quantities of imports of land-intensive agricultural products, such as vegetable oil seeds, vegetable oils and grains (mainly wheat), and raw materials for textiles, such as cotton, wool and raw animal hides and skins. China has no comparative advantage in land-intensive agricultural production and, as found in this study, the values of the revealed comparative advantage indices of these agricultural products have been declining especially quickly since 2003. 
China's agricultural export growth is being driven primarily by the rapid increase in exports of labour-intensive agricultural products, mainly processed agricultural products, followed by animal and horticultural products. China has a comparative advantage in some labour-intensive agricultural production. However, apart from processed agricultural products, whose revealed comparative advantage indices are increasing, the values of the revealed comparative advantage indices for animal and horticultural products have been declining especially quickly since entry into the WTO.

The pattern of China's agricultural trade is consistent with China's comparative advantage and resource endowments. After entry into the WTO, this pattern has been strengthened, indicating that China is moving closer to its comparative advantage in agricultural trade with the rest of the world.

Fast economic growth, structural change and increases in per capita incomes have all played a significant role in driving the changes in comparative advantage in China's agriculture. TBT and SPS measures, however, might also contribute to a rapid decline in China's comparative advantage in labour-intensive animal and horticultural products.

Some agricultural products exported from China are very competitive in world markets. Consequently, importing countries might look to restrict imports from China by setting relatively high SPS standards or by imposing strict inspections in order to protect domestic markets.

China should increase and strengthen SPS levels to meet international standards in order to increase exports of animal and horticultural products to international markets, especially to industrial-country markets. As China faces more SPS disputes, the government needs to initiate bilateral negotiations to counter unfair trade restrictions and discrimination and it could use the WTO to coordinate and resolve trade disputes. As a member of the WTO, China can now participate in the negotiation and establishment of international regulations and standards to obtain a more equal position for its agricultural exports. 


\section{Acknowledgments}

I would like to thank Professor Christopher Findlay for his initial stimulus to write this chapter and for his valuable suggestions and comments. I also would like to thank Shiro Armstrong for helping to collect the trade data. In particular, I would like to thank Professor Ross Garnaut and Dr Ligang Song for their fundamental comments and suggestions in structuring and shaping the chapter.

This chapter is part of the research results of ADP/98-128 project extension funded by the Australian Centre for International Agricultural Research (ACIAR). I would like to thank ACIAR for funding the project.

\section{Notes}

1 China revised its GDP growth rate for the period 1979-2004 in January 2006. The revised GDP growth rate was 9.1 per cent, for 2002, 10 per cent for 2003, 10.1 per cent for 2004 and 9.9 per cent for 2005.

2 China's average tariff level dropped to 9.9 per cent in 2005 compared with 15.6 per cent in 2000 . The average tariff on industrial products dropped to 9.3 per cent compared with 14.8 per cent in 2000 , and that for agricultural products was 15.3 per cent compared with 23.2 per cent in 2000.

3 The classic reference is Ricardo 1817.

4 Ohlin 1933.

5 These three economies on average accounted for 52 per cent of China's total agricultural exports in the period from 2002 to 2004, of which Japan accounted for 31 per cent, the European Union 11 per cent and the United States 10 per cent. 


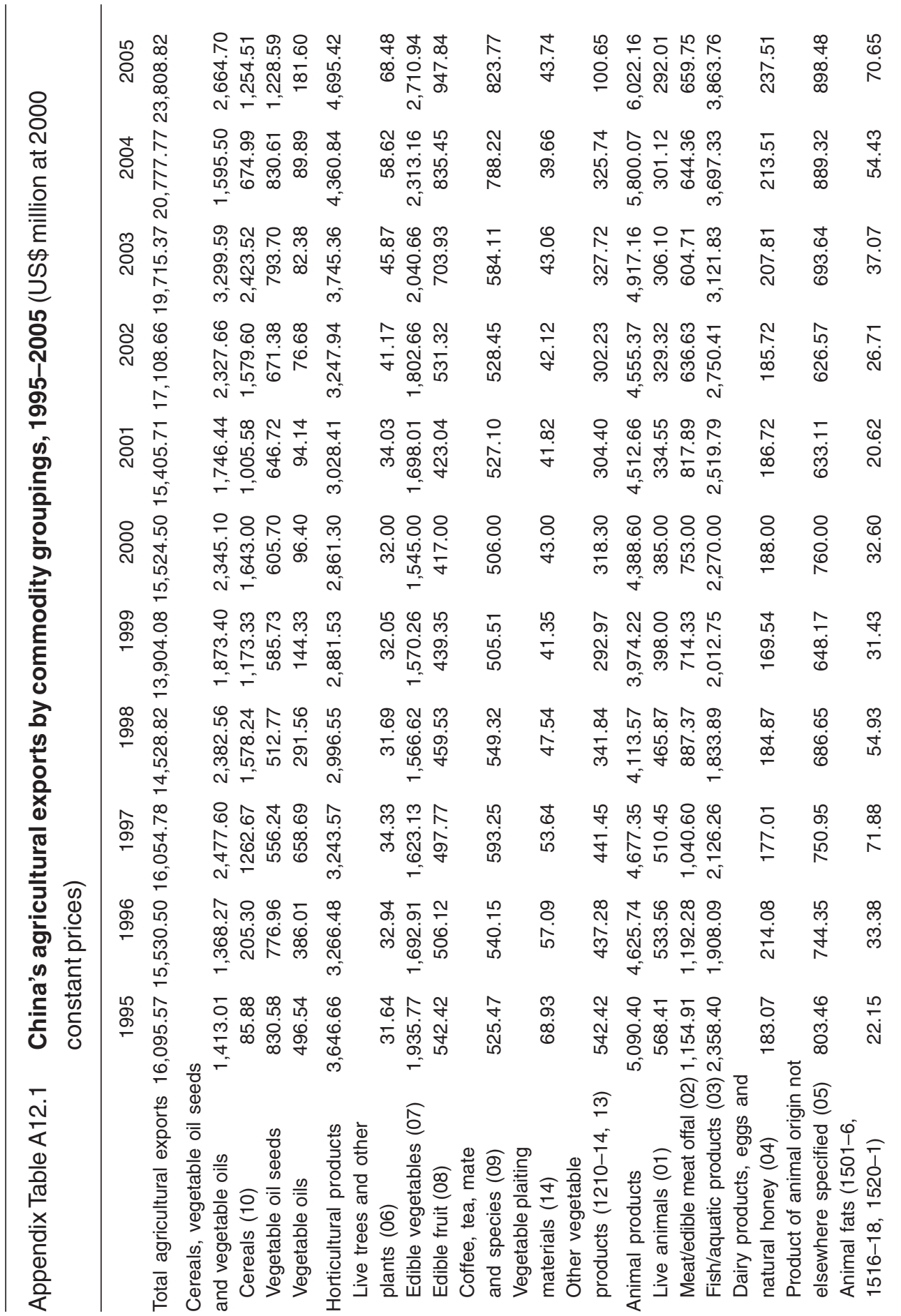




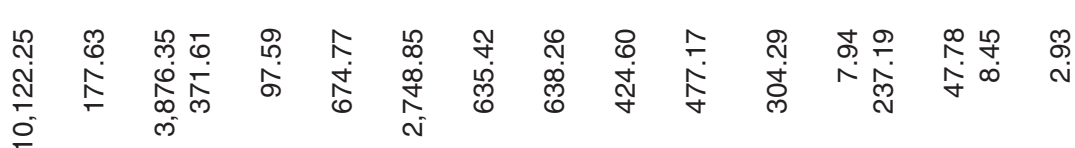

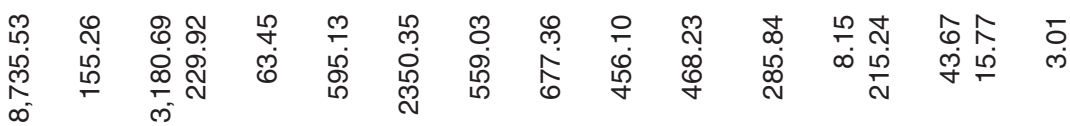

న. ₹

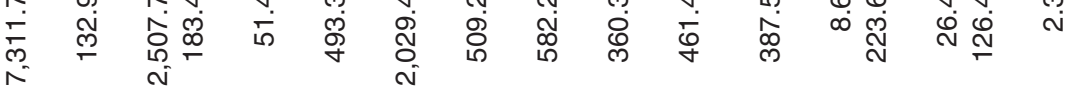

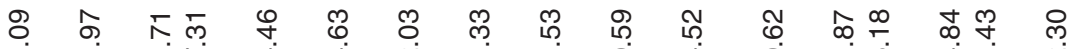

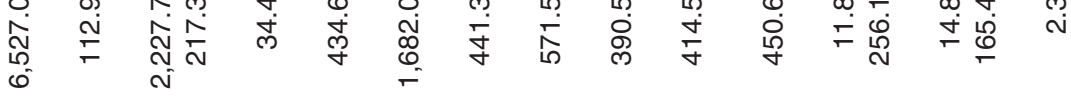

テ

ம்

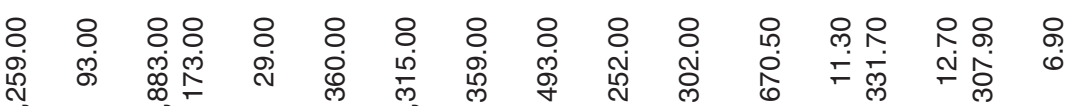

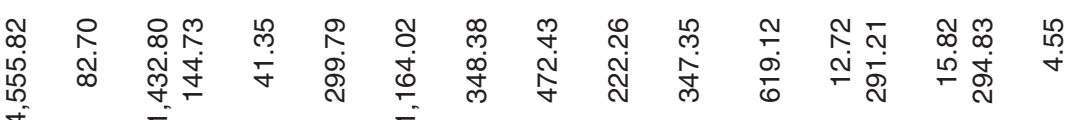

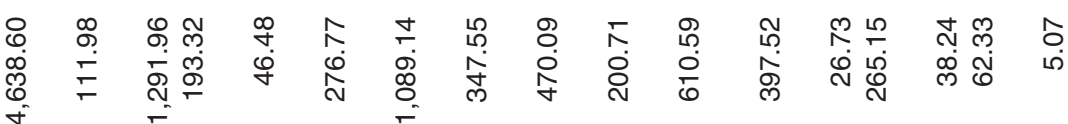

ๆ

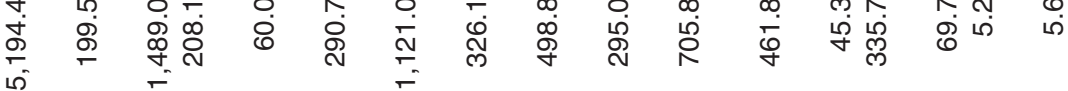

8

क ले N

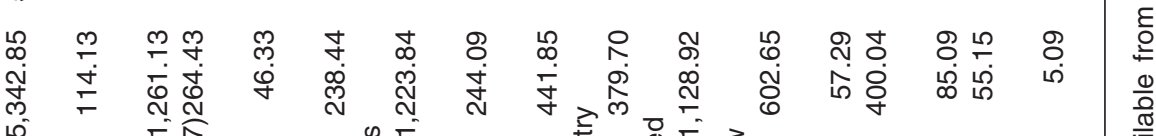

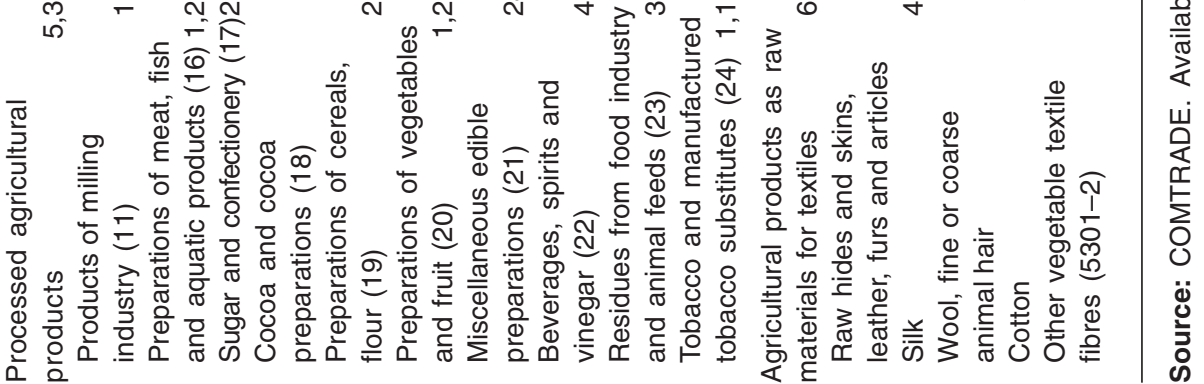




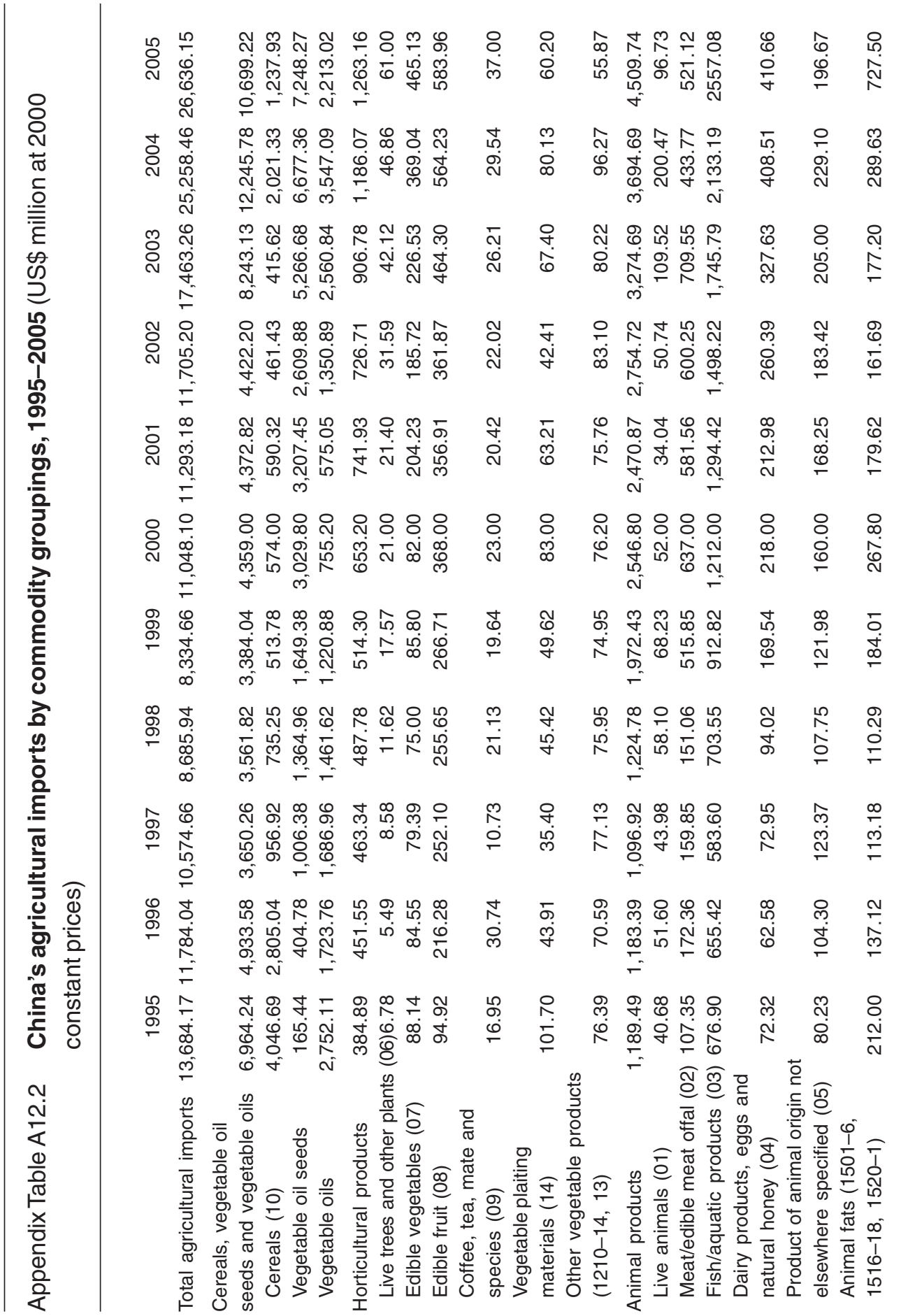


ด ஸे

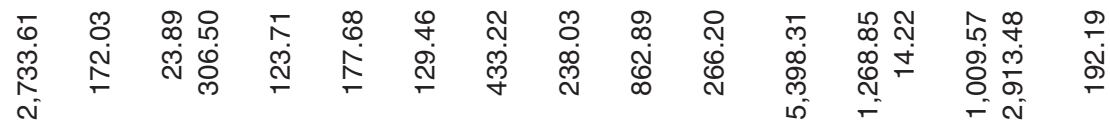

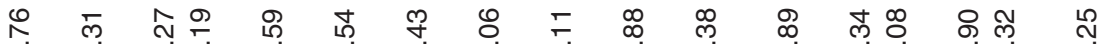

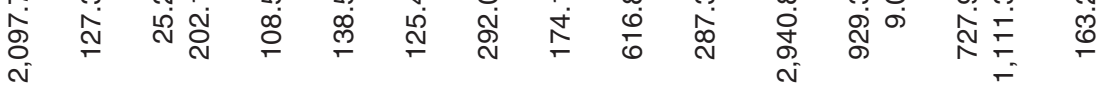

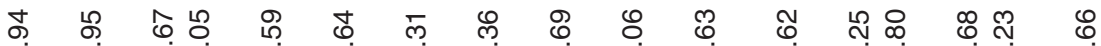
ஜ

ช

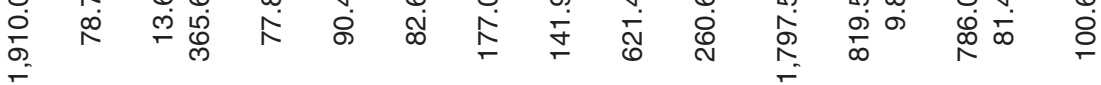

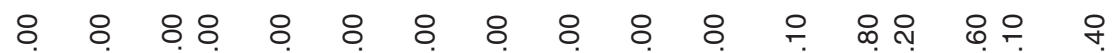
索

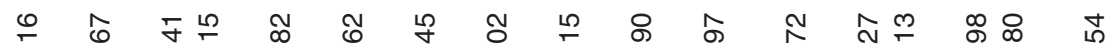
官

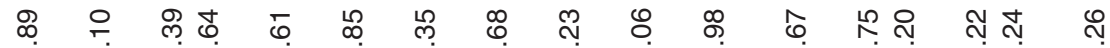
实

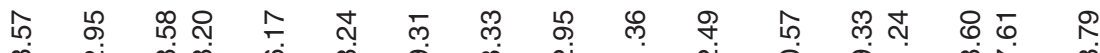

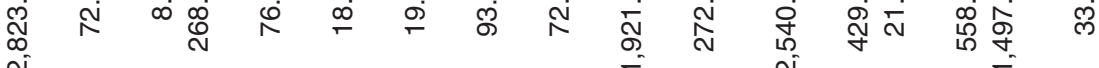
$\infty$ ๑ N œ 峁

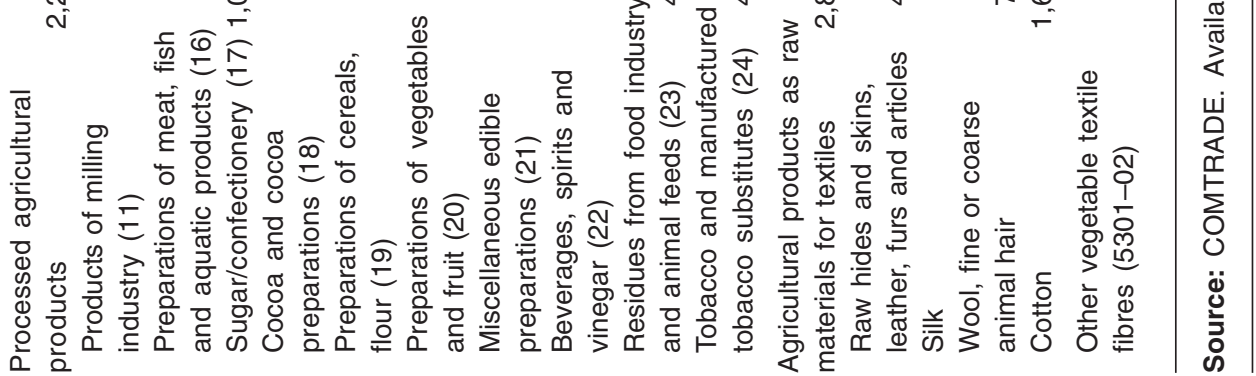




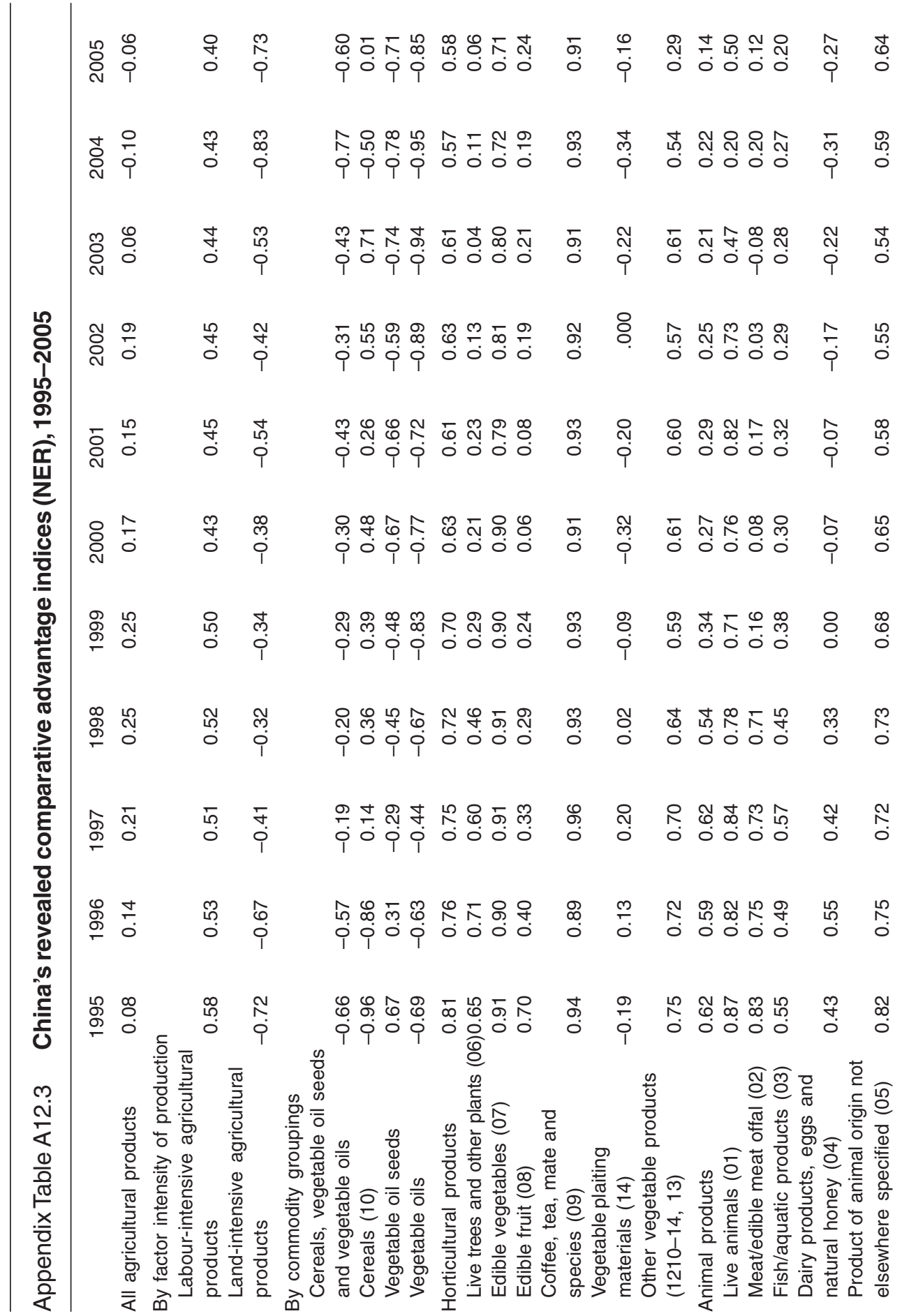




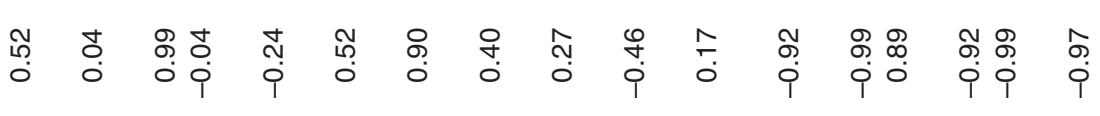

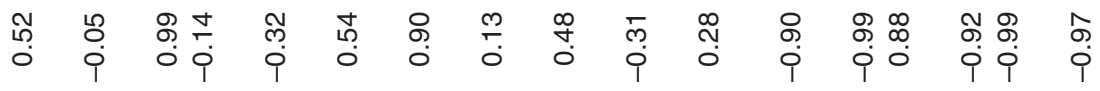

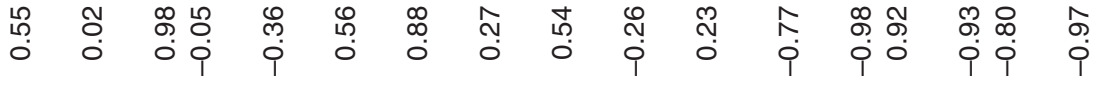

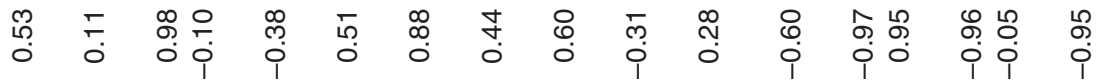

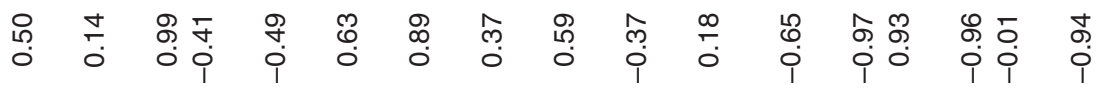

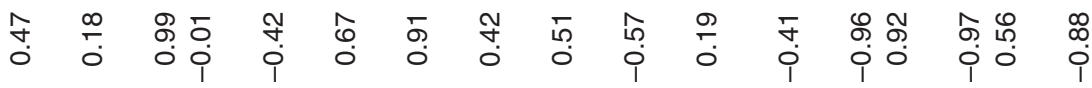

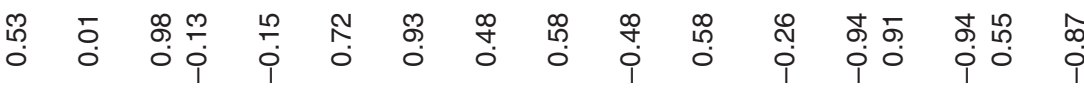

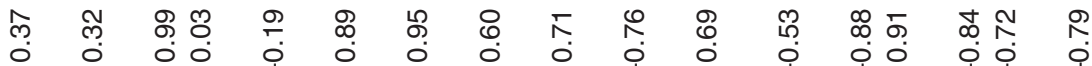

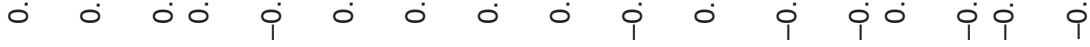

ํㅏㅇ

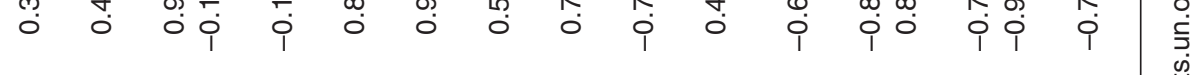

め) ○

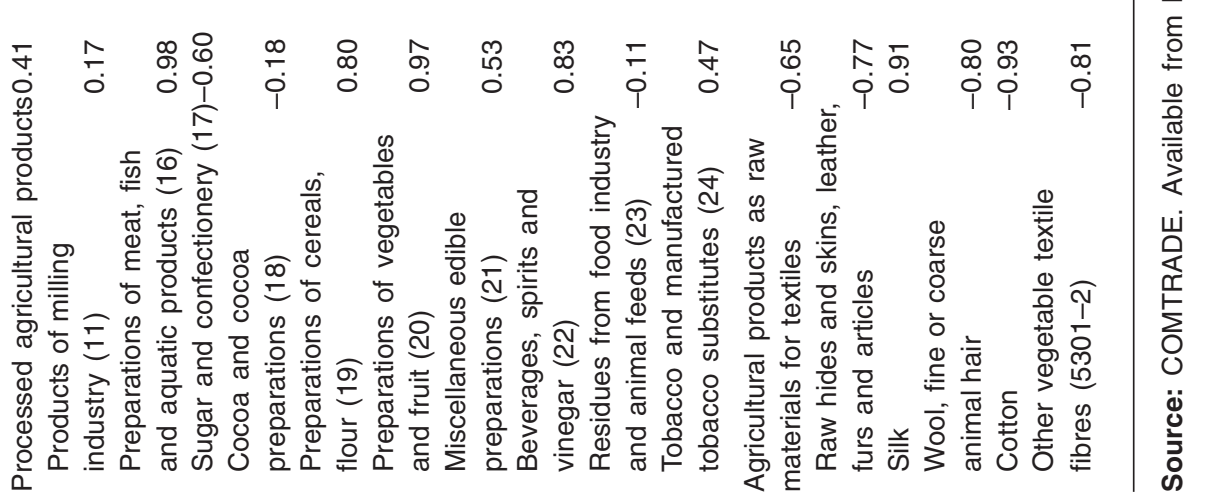

